\title{
PEMBANGUNAN PARIWISATA DAERAH MELALUI PENGEMBANGAN SUMBER DAYA MANUSIA DI GORONTALO
}

\author{
Krishna Anugrah ${ }^{1}$ dan I Wayan Sudarmayasa ${ }^{2}$ \\ 1 Universitas Negeri Gorontalo, 2 Politeknik Negeri Samarinda \\ Email kina_bunny@yahoo.com
}

\begin{abstract}
This study discusses about development of regional tourism through the development of human resources Gorontalo, Sulawesi. The master plan for tourism development in Gorontalo stated that Gorontalo has three areas of community-based tourism development and eight excellent tourist attractions. It was realised that human resources has an important role in the general development as well the development of regional tourism. The approach used in this research is descriptive qualitative, data source obtained from field observation, interview, group discussion and documentation. Local governments have encouraged the development of regional tourism, especially destinations that are around the community through the empowerment of surrounding communities in order to manage the destination well. In order for all aspects of tourism management to run properly it is necessary role of local government in giving encourage and support education field of tourism. So it can fill the shorted of expert workforce to be placed on institutions or tourism related industries.
\end{abstract}

Keywords: Tourism, Development, Human Resources, Gorontalo region

\begin{abstract}
Abstrak
Penelitian ini mengenai pembangunan pariwisata daerah melalui pengembangan sumber daya manusia studi kasus Gorontalo, Sulawesi. Rencana induk pengembangan pariwisata daerah Gorontalo menyebutkan bahwa Gorontalo memiliki tiga kawasan pengembangan pariwisata berbasis masyarakat dan delapan daya tarik wisata unggulan. Peranan sumber daya manusia memiliki peran yang penting dalam keberhasilan pembangunan dan pengembangan kepariwisataan daerah. Pendekatan yang digunakan dalam penelitian ini adalah deskriptif
\end{abstract}


kualitatif, sumber data yang didapatkan berasal dari pengamatan lapangan, wawancara, diskusi grup dan dokumentasi. Pemerintah daerah telah mendorong pengembangan pariwisata daerah terutama destinasi yang berada disekitar masyarakat melalui pemberdayaan masyarakat sekitar agar dapat mengelola destinasi dengan baik. Agar semua aspek dalam pengelolaan kepariwisataan dapat berjalan dengan baik maka diperlukan peran pemerintah daerah dalam memberikan dorongan dan mendukung pendidikan bidang kepariwisataan sehingga dapat mengisi kekosongan tenaga kerja ahli untuk ditempatkan pada lembaga/industri pariwisata.

Kata kunci: Pariwisata, Pembangunan, Sumber daya Manusia, daerah Gorontalo

\section{Pendahuluan}

Membangun pariwisata di daerah yang sedang dalam tahapan penemuan memiliki kompleksitas permasalahan yang harus dapat dicarikan jalan keluarnya, sehingga nantinya diharapkan dapat berjalan sesuai dengan program yang dicanangkan. Pembangunan kepariwisataan merupakan bagian dari pembangunan nasional mempunyai tujuan antara lain memperluas kesempatan berusaha dan lapangan kerja. Kompleksitas dalam pembangunan dan juga tidak terlepas dari kemauan para pemangku kebijakan untuk menggerakkan sektor pariwisata sebagai salah satu pendapatan daerah yang dapat diandalkan.

Di setiap provinsi memiliki keunggulan daerah yang dapat diandalkan sebagai pendapatan daerah. Dengan adanya kekayaan alam tersebut diperlukan tenaga kerja yang memiliki keahlian dan kemampuan yang sesuai dengan bidangnya sehingga pengelolaan tersebut menjadi terarah dan tidak keluar jalur.

Banyak kendala yang dihadapi dalam pembangunan pariwisata di daerah, namun dari semua itu sumber daya manusia yang sebagai pengelola merupakan faktor kunci dalam pembangunan pariwisata daerah. Kemampuan dari sumber daya manusia yang mengelola pariwisata daerah haruslah memiliki kemampuan yang baik dalam keilmuan sehingga dapat menerapkannya pada saat bekerja nanti.

Kusworo dan Damanik (2002) mengatakan bahwa pembenahan sumber daya manusia dan birokrasi belum kuat disuarakan. Terdapat kesan yang cukup menonjol bahwa perhatian kita terutama masih bertumpu pada aspek kuantitatif, yakni seberapa besar devisa, kesempatan kerja, kunjungan wisatawan dan sebagainya, sementara aspek kualitatif yang antara lain dilihat dari perubahan positif mutu sumberdaya manusia cenderung diabaikan. 


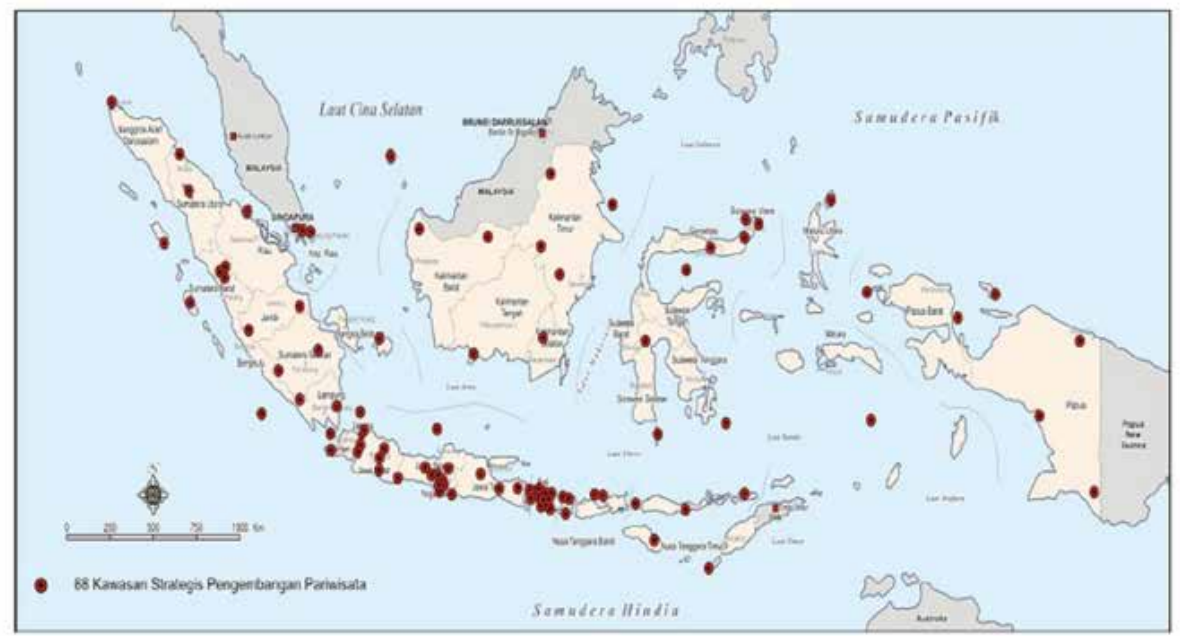

(SUMBER: LAMPIRAN III PP NO 50 TAHUN 2011)

Foto 1. Peta Sebaran 88 (Delapan Puluh Delapan) Kawasan Strategis Pariwisata Nasional

Secara geografis, Gorontalo berada di sebelah barat provinsi Sulawesi Utara dan diapit oleh dua perairan yakni teluk Tomini pada sebelah selatan dan pada sebelah selatan laut Sulawesi. Sumber daya alam yang dimiliki Gorontalo sangat beragam dan dapat beberapa diantaranya dapat dijadikan destinasi wisata.

Rencana induk pengembangan pariwisata daerah Gorontalo (RIPDA) 2012-2027 menyebutkan bahwa Gorontalo memiliki tiga kawasan pengembangan pariwisata berbasis masyarakat dan delapan daya tarik wisata unggulan. Tiga kawasan pengembangan pariwisata berbasis masyarakat tersebut adalah 1) Desa Botutonuo, Kabupaten Bone Bolango; 2) Pantai Olele, kabupaten Bone Bolango; 3) Pantai Monano, Kabupaten Gorontalo Utara. Sedangkan untuk delapan daya tarik wisata unggulan adalah 1) Pentadio Resort, Kabupaten Gorontalo; 2) Museum pendaratan Soekarno, Kabupaten Gorontalo; 3) Benteng Otanaha, Kota Gorontalo; 4) Kawasasan pemandian air panas Lombongo, Kabupaten Bone Bolango; 5) Pantai dan Taman Laut Olele, Kabupaten Bone Bolango; 6) Suaka Margasatwa Hutan Nantu, Kabupaten Boalemo; 7) Pulau Saronde, Kabupaten Gorontalo Utara; 8) Desa Wisata Torosiaje, Kabupaten Pohuwato.

Peraturan Pemerintah Republik Indonesia No 50 tahun 2011 tentang rencana induk pembangunan kepariwisataan nasional tahun 2010-2025 maka provinsi Gorontalo masuk ke dalam salah satu kawasan strategis pariwisata nasional yang berada diurutan nomor 87. Gambar 1 menjelaskan sebaran kawasan strategis pariwisata nasional Indonesia. Kawasan strategis pariwisata nasional untuk provinsi Gorontalo berada di kawasan KotaLimboto dan sekitarnya. Berdasarkan RIPDA dan Peraturan Pemerintah 
tersebut beberapa tahun belakangan pemerintah daerah mulai memberikan perhatian terhadap pengembangan pariwisata daerah. Upaya meningkatkan minat kepariwisataan daerah maka dari tahun ke tahun kegiatan kepariwisataan terus diselenggarakan dan diikuti oleh seluruh Kabupaten dan Kota yang ada di Gorontalo. Dalam setiap satu tahun setiap Kabupaten memiliki jadwal penyelenggaraan kegiatan kepariwisataan dan antara satu kabupaten dengan yang lainnya mengusung tema yang berbeda. Beberapa diantara kegiatan kepariwisataan tersebut direncanakan menjadi kegiatan kepariwisataan yang berskala nasional oleh pemerintah Provinsi Gorontalo.

Selain itu juga pemerintah provinsi mulai membenahi destinasidestinasi yang telah ditetapkan dalam RIPDA agar nampak lebih menarik untuk dikunjungi. Dengan terselenggaranya kegiatan kepariwisataan dan pembenahan destinasi tersebut diharapkan mampu menarik hati calon wisatawan untuk datang melihat kegiatan tersebut dan juga mau mengunjungi destinasi-destinasi lainnya yang berada di Provinsi Gorontalo.

Keberhasilan dalam pembangunan dan pengembangan kepariwisataan daerah bukan hanya dinilai dari banyaknya bangunan yang direvitalisasi hingga pembuatan/pembukaan wisata baru namun lebih daripada itu juga tidak luput dari peranan sumber daya manusianya. Dari rancangan program pembangunan pariwisata daerah lebih diarahkan pada pembenahan fisik semata, hal ini baik dilakukan namun akan menjadi suatu persoalan tersendiri pada masa yang akan datang apabila tidak disertai dengan kesiapan sumber daya manusianya. Pembangunan pariwisata daerah seyogyanya diiringi dengan pembangunan Sumber daya manusia, karena manusia sebagai penggerak majunya kepariwisataan daerah.

Dalam upaya pengembangan tersebut maka diperlukan suatu pembinaan terhadap sumber daya manusia agar nantinya kepariwisataan Gorontalo dapat maju sesuai dengan harapan. Untuk melakukan pembinaan tersebut diperlukan pemetaan kebutuhan terutama kebutuhan bidang keahlian yang diperlukan bagi pelayanan, pengaturan/manajemen organisasi kepariwisataan baik di dalam destinasi maupun di luar destinasi. Dengan demikian diharapkan kepuasan wisatawan dapat terpenuhi dan mau datang kembali, apabila hal tersebut terjadi maka pariwisata Gorontalo dapat hidup dan berkembang.

\section{Metode}

Makalah ini menggunakan pendekatan kualitatif dengan metode deskriptif, yang berdasarkan pada studi kasus. Pendekatan kualitatif adalah suatu proses penelitian dan pemahaman yang berdasarkan pada metodologi yang menyelidiki suatu fenomena sosial dan masalah manusia.

Jenis penelitian kualitatif ini adalah studi kasus yang berada pada Provinsi Gorontalo. Adapun metode pengumpulan data yang penulis gunakan adalah 
dengan 1) Observasi yakni dengan melihat perkembangan kepariwisataan dibeberapa destinasi yang ada di Gorontalo, 2) Wawancara dilakukan dengan masyarakat sekitar destinasi dan praktisi industri pariwisata, serta pemerintah daerah dan 3) Focus group discusion (FGD) yang diselenggarakan dalam upaya pengembangan kepariwisataan daerah yang dihadiri oleh para pemangku kepentingan dibidang pariwisata Gorontalo. 4) Dokumentasi merupakan data didapatkan dari berbagai sumber sehingga mendukung data penelitian, data tersebut antara lain adalah data kunjungan wisatawan ke provinsi Gorontalo, Jumlah sarana akomodasi di Gorontalo, jumlah rumah makan di provinsi Gorontalo.

\section{Peran Pemerintah Daerah}

Dokumen Seri Analisis Pembangunan Wilayah Provinsi Gorontalo 2015, dapat dikatakan bahwa "arah kebijakan dalam pengembangan sektor pariwisata meliputi: pemasaran pariwisata nasional dengan mendatangkan jumlah wisatawan nusantara dan mancanegara; pembangunan destinasi pariwisata dengan meningkatkan daya tarik daerah tujuan wisata sehingga berdaya saing di dalam dan luar negeri; pembangunan industri pariwisata dengan meningkatkan partisipasi usaha lokal dalam industri pariwisata nasional serta meningkatkan keragaman dan daya saing produk dan jasa pariwisata nasional disetiap destinasi pariwisata yang menjadi fokus pemasaran; dan pembangunan kelembagaan pariwisata dengan membangun sumberdaya manusia pariwisata serta organisasi kepariwisataan nasional.”

Upaya mendukung dan menerapkan arah kebijakan tersebut maka pemerintah daerah dalam beberapa tahun belakang ini berupaya membangun pariwisata daerah dengan melibatkan masyarakat. Pertemuan, sosialisasi hingga program-program pembangunan pariwisata diupayakan untuk melibatkan masyarakat lokal yang berada di destinasi, Tujuannya adalah untuk memajukan kehidupan masyarakat tersebut secara perekonomian. Diharapkan masyarakat dapat mandiri dalam mengelola destinasi sehingga meningkatkan kesejahteraan masyarakat lokal. Hal senada dikatakan Ismayanti dalam Rahman dan Tjokropandojo (2014) bahwa pembangunan kepariwisataan pada dasarnya ditujukan untuk beberapa tujuan pokok, salah satunya adalah (1) Meningkatkan pertumbuhan ekonomi; (2) Menghapus kemiskinan; (3) Mengatasi pengangguran; dan (4) Meningkatkan kesejahteraan rakyat.

Beberapa daerah yang memiliki potensi wisata oleh pemerintah daerah difasilitasi dengan membentuk kelompok-kelompok sadar wisata (POKDARWIS) yang terdapat pada destinasi-destinasi, dengan harapan dapat menjadi destinasi yang dapat diandalkan. Pembentukkan kelompok sadar wisata tersebut berasal dari masyarakat sekitar destinasi. Kehadiran kelompok sadar wisata ini diharapkan agar mampu mengelola destinasi 
dan memberikan kontrubusi kepada masyarakat sekitar destinasi baik yang terlibat langsung maupun yang tidak langsung.

Upaya mengembangkan modal sosial masyarakat dilakukan oleh pemerintah daerah dengan memberikan program PNPM mandiri dalam bidang pariwisata, program ini dilaksanakan sekitar tahun 2010 hingga 2013. Beberapa destinasi di provinsi Gorontalo mendapatkan program tersebut bahkan beberapa diantaranya pernah mendapatkan hingga dua tahun berturut-turut. Hasil program yang telah dilakukan tersebut pada beberapa tahun ini masih belum dirasakan maksimal memberikan dampak bagi kemajuan kehidupan masyarakat. Dalam upaya menunjang profesionalisme para pekerja dibidang pariwisata maka Saat ini yang dilakukan oleh pemerintah daerah masih dalam sekedar mensertifikasi para pekerja yang ada di hotel dan guide. Namun dalam memberikan pelatihan bagi sertifikasi bagi pekerja dalam bidang yang berkaitan dengan bidang pariwisata yang masih belum dilakukan dilakukan.

\section{Kondisi Pariwisata Gorontalo}

Berbagai upaya yang dilakukan oleh pemerintah daerah untuk memajukan kepariwisataan. Iklim investasi mulai digiatkan sehingga dapat menumbuhkan sektor usaha dibidang pariwisata dan juga diharapkan dapat memberikan peluang pekerjaan bagi lulusan yang ahli dalam bidang pariwisata.

Tabel 1. Fasilitas kepariwisataan di Provinsi Gorontalo hingga tahun 2016

\begin{tabular}{lc}
\hline Fasilitas & Jumlah \\
\hline Akomodasi & 90 \\
Rumah Makan & 101 \\
Biro Perjalanan Wisata & 22 \\
Penyewaan Kendaraan & 29 \\
\hline
\end{tabular}

Sumber: Dinas Pariwisata Provinsi Gorontalo

Penyebaran data tersebut di atas paling banyak terdapat di Kota Gorontalo. Hampir sebanyak kurang lebih 60\% penyebarannya terdapat di Kota Gorontalo terutama fasilitas akomodasi. Hal ini dikarenakan Kota Gorontalo sebagai Ibukota Provinsi Gorontalo sehingga fasilitas tersebut lebih banyak hadir dan dapat dengan mudah dimanfaatkan oleh wisatawan. Selain itu beberapa destinasi yang lebih dikenal oleh wisatawan lebih dekat dengan Kota Gorontalo. Sehingga aksesbilitas lebih mudah dan tidak membutuhkan waktu yang lama untuk sampai di destinasi.

Jumlah kunjungan wisatawan ke Gorontalo sempat mengalami kenaikan sebelum tahun 2016. Namun pada tahun 2016 jumlah wisatawan mengalami penurunan yang cukup banyak, hampir setengah jumlah kunjungan pada 
tahun 2015. Hal ini dapat disebabkan oleh beberapa faktor antara lain 1) minat kunjungan wisatawan ke destinasi menurun dikarenakan oleh atraksi yang ada sudah tiada baik itu rusak karena faktor alami ataupun dikarenakan faktor pengelolaan destinasi yang kurang baik, 2) faktor pelayanan yang diberikan oleh fasilitas yang ada kurang memuaskan wisatawan. 3) Faktor kondisi cuaca yang kurang mendukung sehingga wisatawan yang sudah tiba kecewa dikarenakan tidak dapat mengunjungi destinasi hal ini terutama terjadi pada destinasi yang berhubungan dengan alam, contoh taman laut olele, hiu paus. Adapun jumlah kunjungan wisatawan dapat dilihat pada tabel 2.

\section{Gambaran Penyelenggaraan Pendidikan Pariwisata di Gorontalo}

Tempat penyelenggaraan pendidikan formal khususnya dalam bidang kepariwisataan telah hadir di provinsi Gorontalo akan tetapi setiap daerah tidak sama jumlahnya. Tempat pendidikan tersebut adalah tingkat Sekolah Menengah Kejuruan yang di dalamnya terdapat jurusan Pariwisata ataupun perhotelan, sedangkan untuk tingkat perguruan tinggi hanya terdapat disatu Universitas Negeri saja.

Tabel 2 Jumlah Total Kunjungan Wisatawan di Provinsi Gorontalo tahun 2013-2016

\begin{tabular}{cc}
\hline Tahun & Jumlah wisatawan (orang) \\
\hline 2013 & 159.114 \\
2014 & 366.033 \\
2015 & 576.151 \\
2016 & 225.155 \\
\hline
\end{tabular}

Sumber: Dinas Pariwisata Provinsi Gorontalo.

Minat masyarakat untuk mengenyam pendidikan pariwisata masih sangat rendah. Beberapa sekolah masih mempunyai murid yang sedikit jika dibandingkan dengan sekolah yang lain di luar Gorontalo demikian pula untuk tingkat universitas. Jumlah sekolah menengah kejuruan bidang pariwisata yang berada di Kota Gorontalo hanya terdapat 2 sekolah, yakni SMKN 1 Kota Gorontalo dengan jumlah lulusan rata-rata sebanyak 30 orang per tahun dengan kompetensi usaha perjalanan wisata, SMKN 2 Kota Gorontalo rata-rata jumlah lulusan sebanyak 90 orang per tahun dengan kompetensi perhotelan dan jasa boga, SMKN 1 Limboto dengan jumlah rata-rata lulusan 60 orang per tahun dengan kompetensi usaha perjalanan wisata, SMKN 1 Boalemo dengan jumlah rata-rata lulusan 30 orang per tahun dengan kompetensi bidang perhotelan dan Universitas Negeri ratarata jumlah lulusan hanya 15 orang per tahun.

Dari data jumlah lulusan tersebut di atas, dapat diartikan bahwa lulusan SMK dan universitas adalah sumber daya yang potensial yang siap digunakan 
oleh industri kepariwisataan. Namun disisi lain lulusan yang dari smk tidak banyak melanjutkan studi ke jenjang perguruan tinggi dan sebagian besar mencari pekerjaan di industri lainnya selain bidang pariwisata. Apabila hal ini terus berlangsung maka dalam beberapa kurun waktu di masa akan datang akan menimbulkan dampak yang kurang baik bagi pengembangan pariwisata. Sumber daya manusia yang memiliki keahlian dalam bidang pariwisata jumlahnya terbatas. Pengembangan pariwisata harus diiringi dengan ketersediaan jumlah sumber daya manusianya sebagai penggerak pembangunan itu sendiri.

\section{Upaya Meningkatkan Kualitas Sumber Daya Manusia}

Pembangunan pariwisata berkelanjutan atau Sustainable Tourism Development menurut Yaman dan Mohd (2004, dalam Nurhidayati 2012) ditandai dengan empat kondisi yaitu: (1) Anggota masyarakat harus berpartisipasi dalam proses perencanaan dan pembangunan pariwisata, (2) Pendidikan bagi tuan rumah, pelaku industri dan pengunjung/wisatawan, (3) Kualitas habitat kehidupan liar, penggunaan energi dan iklim mikro harus dimengerti dan didukung, (4) Investasi pada bentuk-bentuk transportasi alternative.

Upaya pengembangan destinasi yang berkelanjutan di provinsi Gorontalo, terutama yang terdapat masyarakat sekitar oleh pemerintah dilibatkan dalam proses perencanaan dan pembangunan pariwisata, pemerintah mengundang pemangku kepentingan yang berada disekitar destinasi seperti lurah dan ketua POKDARWIS sebagai representatif masyarakat, dalam Focus Group Discussion (FGD) untuk pengembangan destinasi dimasing-masing destinasi. Masyarakat diberikan suatu bentuk pelatihan dan pemahaman tentang kepariwisataan melalui sosialisasi sadar wisata dan program lainnya. Akan tetapi pemberian pemahaman ataupun edukasi kepada wisatawan belum dilakukan secara maksimal. Hal ini perlu dilakukan dalam upaya melakukan pelestarian baik itu budaya maupun lingkungan sekitar menjadi terjaga. Agar lestari perlu upaya sosialisasi yang secara terus menerus baik itu berupa tulisan maupun lisan kepada wisatawan yang dapat dilakukan oleh masyarakat hingga pelaku industri pariwisata.

Di provinsi Gorontalo pendidikan formal bidang pariwisata hanya terdapat pada level sekolah menengah kejuruan dan perguruan tinggi. Apabila dilihat data yang ada pada jenjang sekolah menengah kejuruan hanya mempersiapkan sumber daya yang siap bekerja sesuai dengan bidang keahlian yang ada. Apabila ditelaah maka terjadi ketimpangan dalam sumber daya yang dihasilkan dengan jumlah industri yang ada sehingga hal ini dapat menimbulkan pengangguran, di sisi yang lain perguruan tinggi juga memiliki peran yang sama yakni sebagai tempat menyiapkan sumber daya manusia pariwisata yang bukan hanya mengasah keahlian tetapi juga 

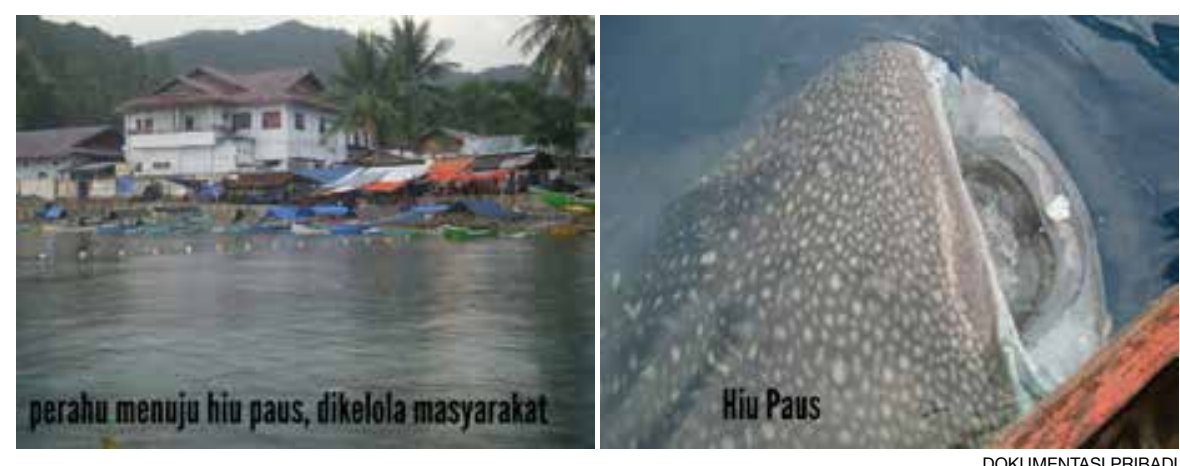

Foto 2. Perahu untuk wisata ikan pau yang dikelola warga setempat, dan ikan paus kanan.

pelayanan, masih terdapat kesan yang kurang tepat dari penggunaan peralatan tersebut. Sedangkan dibeberapa tempat sikap ramah dalam menyambut kedatangan tamu dan memberikan pelayanan sudah dilakukan.

\subsection{Sumber Daya Manusia Ujung Tombak Pembangunan Kepari- wisataan}

Persaingan yang semakin ketat saat ini telah membuat destinasi-destinasi berlomba berusaha memberikan nilai lebih pada wisatawan sehingga tertarik dan mau mengunjungi destinasi-destinasi. Nilai lebih ini merupakan harapan wisatawan sehingga hal ini dianggap sebagai bentuk respon atau ketanggapan terhadap pemenuhan kebutuhan wisatawan. Apabila kebutuhan wisatawan terpenuhi maka akan berdampak pada kepuasan, sehingga wisatawan mau datang kembali dan bahkan merekomendasikan kepada kerabat mereka agar para kerabat tersebut mau mengunjungi destinasi tersebut. Hal senada dikatakan oleh Zeithaml, et al dalam Utama (2014) kepuasan konsumen merupakan pemenuhan respon konsumen.

Sebaik dan sebagus apapun fasilitas destinasi yang disediakan untuk wisatawan apabila tidak disertai dengan pengelolaan yang baik maka tidak akan menimbulkan kepuasan bagi wisatawan. Kunci dari pengelolaan yang baik tersebut berada di sumber daya manusia yang bekerja mengelola destinasi-destinasi tersebut. Sumber daya manusia tersebut meliputi semua unsur baik itu masyarakat yang berada disekitar destinasi sebagai pengelola destinasi, pemerintah, dan praktisi pariwisata. Apabila semua unsur dapat bekerja dan menjalin kerjasama yang baik maka kesuksesan pembangunan kepariwisataan dapat dicapai.

Pemberian pelayanan yang berkualitas juga turut menunjang kesuksesan pembangunan. Ukuran kualitas pelayanan seperti yang dikemukakan Kirom (2010) dalam bukunya "Mengukur Kinerja Pelayanan dan Kepuasan Konsumen" dikemukakan bahwa kualitas pelayanan dapat di ukur dari beberapa komponen antara lain Nilai Kerja, Semangat Kerja, dan Komunikasi. Masyarakat masih terdapat kesan canggung dalam 


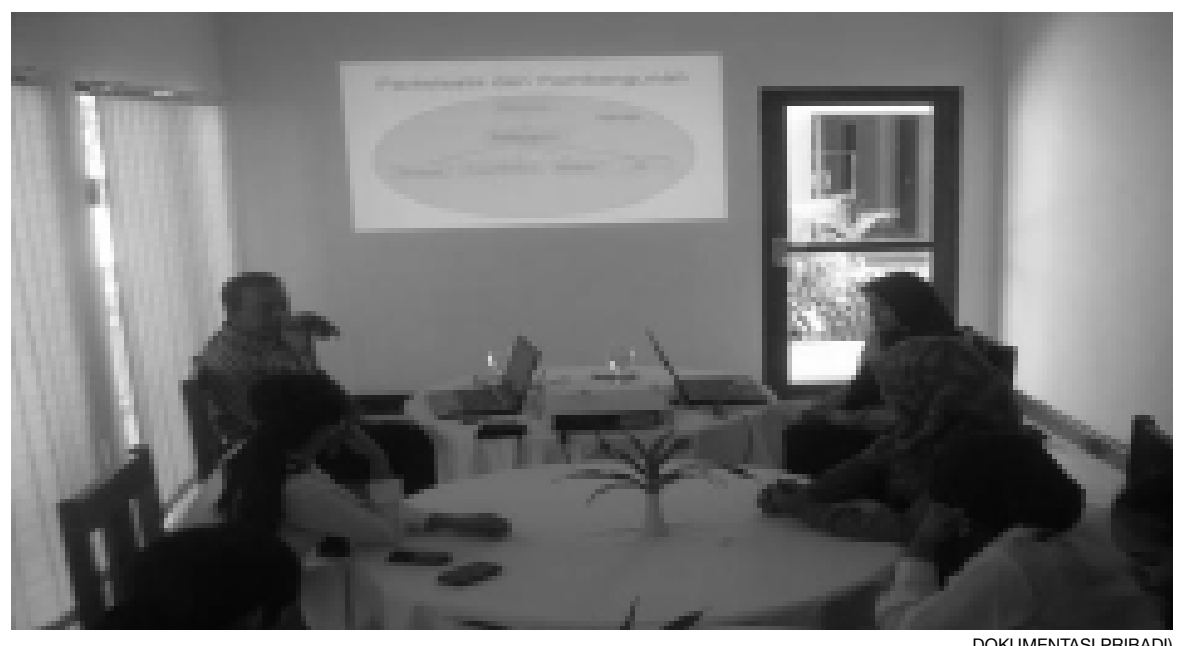

Foto 3- Kegiatan Diskusi IImiah kepariwisataan di Perguruan Tinggi Gorontalo

memberikan pelayanan kepada wisatawan terutama wisatawan asing yang datang, hal ini dikarenakan masyarakat masih ada mengalami kendala dalam berkomunikasi terutama dalam berbahasa asing. Dalam keterampilan berkomunikasi ini bukan hanya bahasa saja yang sangat diharapkan, namun juga bagaimana cara orang/pemandu di dalam gaya berbicara, etika berbicara, sopan santun serta sifat dan perilaku si penyedia komunikasi tersebut. Kesan canggung dalam berkomunikasi pada akhirnya dapat menimbulkan ketidakpuasan dalam pelayanan sehingga dapat berdampak terhadap keinginan wisatawan untuk datang kembali dan mempromosikan kepada kerabat dengan demikian dapat berakibat pada menurunnya jumlah kunjungan wisatawan. Menurunnya jumlah kunjungan wisatawan dapat berdampak pada menurunnya semangat kerja dan nilai kerja.

\subsection{Sumber Daya Manusia sebagai Alat peningkatan Mutu Kualitas Produk}

Dalam Pariwisata Sumber daya Manusia sebagai salah satu bagian yang terpenting sebagai alat untuk meningkatkan bagaimana mutu dari suatu kualitas produk itu ditentukan oleh bagaimana kualitas sumber daya manusia menentukan mutu dari kualitas produk Pariwisata. Salah satu prosedur yang mesti dilakukan untuk peningkatan mutu Kualitas Produk antara lain penerapan fungsi-fungsi yang ada dalam Manajemen Sumber Daya Manusia seperti halnya pada proses penarikan tenaga kerja perlu dilakukan dan dipilih yang memang berkompeten dalam bidang Pariwisata. Pekerja bidang pariwisata banyak yang bukan dari latar belakang pendidikan pariwisata, salah satu contoh yang dapat ditemui adalah pekerja restoran/ rumah makan yang mandiri dalam artian tidak menjadi bagian produk 


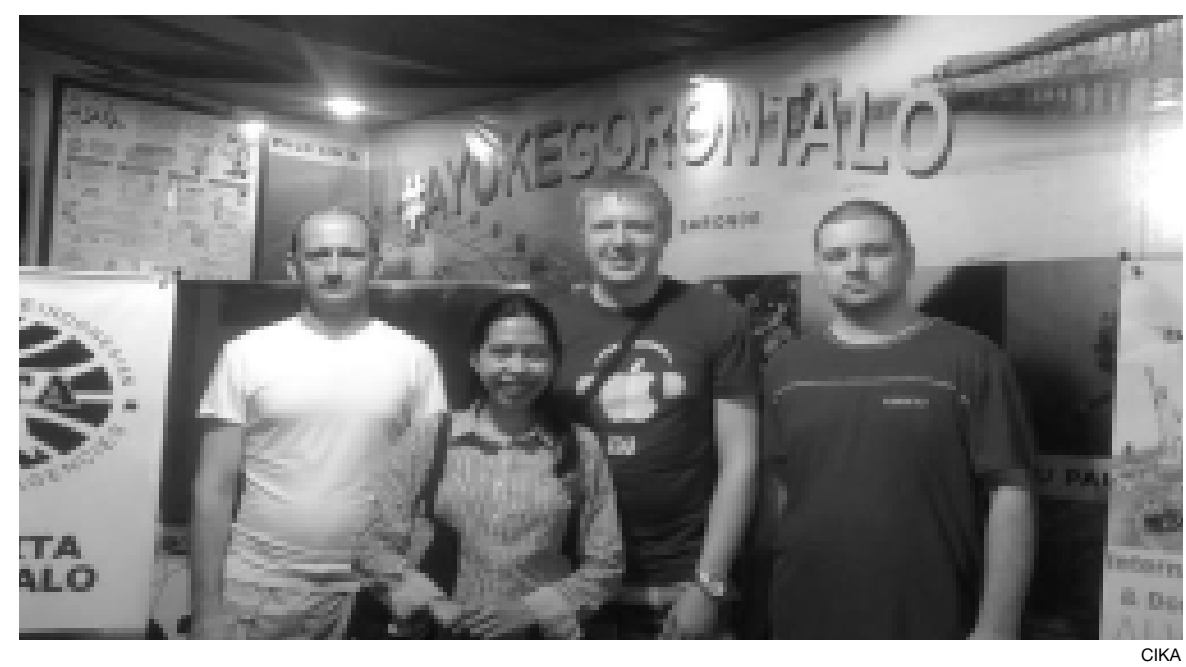

Foto 4. Pemandu wisata bersama Wisatawan Asing yang datang ke Gorontalo

hotel. Para pelayan restoran kebanyakan direkrut dari yang bukan berlatar belakang pendidikan pariwisata. Kesan yang terjadi banyak yang tidak menguasai produk yang dijual sehingga tidak dapat menjelaskan produk apabila tamu menanyakan. Hal ini memang bukan suatu keharusan bahwa semua pekerja bidang pariwisata berlatar belakang pendidikan pariwisata. Akan tetapi untuk bidang pekerjaan yang berhubungan langsung dengan pelayanan tamu maka menjadi keharusan sehingga pelayanan yang berikan terkesan lebih berkualitas dan profesional. Bagi sumber daya manusia yang belum berlatar belakang pendidikan pariwisata maka juga perlu diberikan program pendidikan dan latihan bidang pariwisata.

Keilmuan dalam bidang pariwisata memiliki perbedaan dengan keilmuan bidang lainnya oleh karena penting dilakukan program pendidikan dan pelatihan bidang pariwisata bagi sumber daya manusia yang belum pernah mengikutinya. Melalui program pendidikan dan pelatihan diharapkan kemampuan sumber daya manusia yang dimiliki akan semakin baik dan menjadi ahli dalam bidangnya.

Maju dan mundurnya Kepariwisataan di Gorontalo sangat tergantung akan kualitas Sumber Daya manusia yang dimiliki. Untuk itulah maka semua komponen yang berkepentingan harus secara bersama-sama memiliki serta mewujudkan arah daripada kemajuan kepariwisataan di Gorontalo. Semua komponen seperti para stakeholder atau pembuat kebijakan haruslah mendorong dan mendukung pengembangan sumber daya manusia pariwisata, dalam hal ini adalah lembaga-lembaga pendidikan yang ada di Gorontalo untuk mencetak kualitas dari pengajarnya serta menghasilkan output yang bagus.

\section{Simpulan}


Berdasarkan dari beberapa permasalahan serta peluang-peluang yang ada, pengembangan pariwisata Gorontalo akan bisa berkembang dengan baik apabila dilakukan tiga hal berikut.

Pertama, sumber daya manusia bidang pariwisata di Gorontalo masih perlu dibenahi. Terutama kesadaran dan keikhlasan dalam memberikan pelayanan kepada tamu yang datang. Karena bidang pariwisata merupakan pelayanan jasa yang lebih cenderung mengutamakan pelayanan. Sehingga wisatawan yang datang langsung dapat menikmati pelayanan tersebut dan merasakan kepuasan pada saat menikmati pelayanan tersebut.

Kedua, investasi sumber daya manusia yang memiliki keahlian dalam bidang pariwisata merupakan investasi jangka panjang. Karena diperlukan proses yang panjang dalam menjadikan seseorang menjadi berkualitas. Agar semua aspek pengelolaan kepariwisataan dapat berjalan dengan baik diperlukan peran pemerintah daerah dalam memberikan mendorong dan mendukung pendidikan bidang kepariwisataan. Sehingga dapat mengisi kekosongan tenaga kerja ahli untuk ditempatkan pada lembaga/industri lainnya seperti destinasi.

Ketiga, intensitas pelatihan dalam bidang yang berkaitan dengan pariwisata masih sedikit dilakukan sehingga perlu diadakan lebih intens dengan demikian diharapkan semua sektor dapat mendukung kemajuan pariwisata Gorontalo.

\section{Daftar Pustaka}

Alfarisi, Ikhwan Kunto. 2009. Peranan Pendidikan Dalam Meningkatkan Sumber Daya Manusia. Diunduh tanggal 8 juli 2013 dari http://www.wikimu.com/ news/DisplayNews.aspx?id=13054.

Kusworo, Hendri Adji dan Janianton Damanik. 2002. "Pengembangan SDM Pariwisata Daerah”. Jurnal Ilmu Sosial \& Ilmu Politik,Vol. 6, No.1, Juli 2002, p.1-2.

Kirom, Bahrul. 2010, Mengukur Kinerja Pelayanan dan Kepuasan Konsumen, Bandung, Pustaka Reka Cipta

Nurhidayati, Sri Endah. 2012. Prinsip Dasar Community Based Tourism (Cbt). Diunduh tanggal 11 April 2014 dari http://endah-parwis-fisip.web.unair.ac.id/ artikel_detail-70079-Artikel-Prinsip\%20dasar\%20community\%2obased\%20 tourism\%20\%28cbt\%29.Html.

Nandi. 2016. Pariwisata dan Pengembangan Sumberdaya Manusia. Diunduh tanggal o6 Oktober 2016 jam 15:45 dari ejournal.upi.edu/index.php/gea/article/ download/1689/1140.

Peraturan Pemerintah No 50 Tahun 2011 tentang rencana induk pembangunan kepariwisataan nasional tahun 2010-2025

Rahman, Nur Abdu dan Tjokropandojo, Dewi Sawitri. 2014. Kapasitas Sumber Daya Manusia Lokal Pada Industri Pariwisata Perhotelan di Kelurahan Kuta. Jurnal 
Perencanaan wilayah dan Kota B SAPPK V3N2, p.364.

Rencana Induk Pengembangan Pariwisata Daerah Provinsi Gorontalo 2012-2027.

Seri Analisis Pembangunan Wilayah Provinsi Gorontalo 2015. Diunduh tanggal 23 September 2016 dari http://simreg.bappenas.go.id/document/Publikasi/ DokPub/Analisis\%2oProvinsi\%20Gorontalo\%202015_ok.pdf.

Utama, I Gusti Bagus Rai. 2014. Pengantar Industri Pariwisata, tantangan dan peluang bisnis kreatif. Yogyakarta. Deepublish.

\section{Profil Penulis}

Krishna Anugrah adalah alumnus Sekolah Tinggi Pariwisata Bali (DIV), Universitas Udayana Kajian Pariwisata (S2), Dosen Jurusan Pariwisata di Universitas Negeri Gorontalo. Email: kina_bunny@yahoo.com

I Wayan Sudarmayasa, S.ST.Par, M.Par. adalah alumnus Universitas Udayana (S1), Universitas Udayana Kajian Pariwisata (S2), Dosen Jurusan Pariwisata di Politeknik Negeri Samarinda. Email: I_w_sudarmayasa@polnes.ac.id 